PEMBELAJAR: Jurnal Ilmu Pendidikan, Keguruan, dan Pembelajaran

Volume 2 Nomor 1 April 2018 hal 35-43

e-ISSN: 2549-9114 dan p-ISSN: 2549-9203

(Received: Februari-2018; Reviewed: Maret-2018; Published: April 2018)

\title{
Pengaruh Metode Proyek Terhadap Kemampuan Kognitif Anak Di Kelompok B2 Tk Aisyiyah Maccini Tengah
}

\author{
Herman $^{a}$, Rusmayadi ${ }^{a}$ \\ aProgram Studi PGPAUD Fakultas Ilmu Pendidikan Universitas Negeri Makassar \\ Email : herman-hb83@unm.ac.id
}

\begin{abstract}
Abstrak. Permasalahan dalam penelitian ini adalah 1. Bagaimana kemampuan kognitif anak dikelompok B2 TK Aisyiyah Maccini Tengah Kota Makassar sebelum dan sesudah diberikan perlakuan metode proyek? Kemampuan kognitif anak sebelum diberikan perlakuan metode proyek dapat dilihat bahwa anak belum mampu untuk menghubungkan, menilai, dan mempertimbangkan. Setelah anak diberikan perlakuan metode proyek anak sudah mampu untuk menghubungkan, menilai, dan mempertimbangakan sesuatu yang ia kerjakan. 2. Apakah ada pengaruh metode proyek tehadap kemampuan kognitif anak dikelompok B2 TK Aisyiyah Maccini Tengah Kota Makassar? tujuan penelitian ini adalah untuk mengetahui pengaruh metode proyek terhadap kemampuan kognitif anak dikelompok B2 TK Aisyiyah Maccini Tengah Kota Makassar. Kegiatan metode proyek yang dilakukan adalah Mengelompokkan bentuk-bentuk geometri, mengurutkan angka 1-20, menyusun pola balok. Pendekatan yang digunakan dalam penelitian ini adalah pendekatan kuantitatif. Jenis penelitian adalah eksperimen sederhana. Ada dua variabel yang akan diteliti dalam penelitian ini yaitu variabel bebas dan variabel terikat. Dengan desain penelitian One GroupPretest-posttest Design. Definisi operasional variabel. Populasi dan sampel dalam penelitian ini berjumlah 16 anak. Teknik pengumpulan data melalui teknik observasi dan dokumentasi. Prosedur pengumpulan data dilakukan melalui perencanaan, pemberian pretest, pemberian perlakuan, pemberian posttest dan analisis hasil. Teknik analisis data yang digunakan adalah uji beda Wilcoxon. Hasil penelitian menunjukkan bahwa kemampuan kognitif anak mengalami peningkatan perolehan nilai dibandingkan sebelum perlakuan. Dari hasil penelitian yang dilakukan menunjukkan bahwa kemampuan kognitif anak mengalami peningkatan perolehan nilai yang dibandingkan sebelum diberikan perlakuan dengan nilai $\mathrm{T}$ hitung (136) > T tabel (30) dan $\mathrm{Z}$ hitung $(3.51)>\mathrm{Z}$ tabel $(1,645)$, dengan demikian bahwa hipotesis diterima. Maka dapat disimpulkan bahwa ada pengaruh metode proyek terhadap kemampuan kognitif anak dikelompok B2 TK Aisyiyah Maccini Tengah Kota Makassar.
\end{abstract}

Kata Kunci: Kemampuan Kognitif, Kelomok Anak, Metode Proyek

Abstract. The research problem is 1. How cognitive abilities of children grouped B2 TK Aisyiyah Middle Maccini of Makassar before and after the treatment methods of the project? Cognitive abilities before being given treatment methods of the project can be seen that the children are not able to connect, assess, and expensive. After the child is given treatment methods of the project children are able to connect, assess, and mempertimbangakan something he was doing. 2 . Is there any influence tehadap project method cognitive abilities of children grouped B2 TK Aisyiyah Middle Maccini Makassar City? the purpose of this study was to determine the effect of the methods of the project on children's cognitive abilities grouped B2 TK Aisyiyah Middle Maccini Makassar. Activity methods of the projects is Grouping geometric shapes, sorting numbers 1-20, construct beam patterns. The approach used in this study is the quantitative approach. This type of research is a simple experiment. There are two variables that will be examined in this study is the independent variable and the dependent variable. One study design with GroupPretest-posttest design. Operational definitions of variables. Population and sample in this study amounted to 16 children. The technique of collecting data through observation and documentation. Data collection procedures done through the planning, provision of pretest, giving treatment, posttest administration and analysis of results. Data analysis technique used is different Wilcoxon test. The results showed that the cognitive abilities of children increased acquisition value than before the treatment. From the research carried out showed that the cognitive abilities of children increased acquisition value than before given treatment to the value $\mathrm{T}$ 
count (136)> $\mathrm{T}$ table (30) and $\mathrm{Z}$ count (3:51)> $\mathrm{Z}$ table (1.645), so that the hypothesis is accepted, It can be concluded that there is influence of the methods of the project on children's cognitive abilities grouped B2 TK Aisyiyah Middle Maccini Makassar.

Keywords: Cognitive Ability, groups of children, Project Method

(O2018 -Pembelajar Universitas Negeri Makassar. Ini adalah artikel dengan akses terbuka dibawah licenci CC BY-NC-4.0 (https://creativecommons.org/licenses/by-nc/4.0/).

\section{PENDAHULUAN}

Pendidikan anak usia dini merupakan jenjang pendidikan prasekolah yang berumur 0 6 tahun, oleh karena itu anak usia dini menggali pengalaman-pengalaman langsung tentang apa yang dialaminya melalui pengoptimalan panca indera yang ada disekitarnya. Sehingga anak dapat belajar melalui apa yang dilihat, didengar dan dirasakan, lalu mereka meraba, mempelajari serta membuat kesimpulan akhir tentang pengamatan yang mereka lakukan.

Pembelajaran pada anak usia dini hendaknya melalui interaksi langsung dengan objek-objek nyata, dan pengalaman konkret dengan menggunakan berbagai media dan sumber belajar, agar apa yang dipelajari anak menjadi lebih berkesan dan bermakna, karena dengan dihadapkannya dengan benda-benda konkret anak lebih mudah mengigat suatu kejadian yang dialaminya secara langsung dibanding ketika anak hanya disuruh membayangkan suatu kegiatan.

Sebagaimana dalam Undang-undang nomor 20 tahun 2013 pada Bab I pasal 1 ayat 14 yang dikemukakan oleh Sujiono (2011: 6) sebagai berikut:

Pendidikan anak usia dini adalah suatu upaya pembinaan yang ditujukan kepada anak sejak lahir sampai dengan usia enam tahun yang dilakukan melalui pemberian rangsangan pendidikan untuk membantu pertumbuhan dan perkembangan jasmani dan rohani agar anak memiliki, kesiapan dalam memasuki pendidikan yang lebih lanjut.
Untuk membangun suatu pengetahuan pada anak usia dini, kita perlu mengunakan beberapa metode agar pengetahuan anak dapat berkembang dengan baik, olehnya itu dalam penelitian ini peneliti menggunakan metode proyek agar anak mampu bersosialisasi dengan temannya dan mampu memecahkan suatu masalah yang dihadapi dalam kehidupan sehariharinya.

Aspek-aspek perkembangan anak dapat berkembang dengan pesat, pada usia dini, apabila anak dilatih untuk mengembangkan aspek perkembangannya sehingga aspek perkembangan yang dimiliki anak dapat berkembang dengan baik. Olehnya itu untuk mengembangkan salah satu aspek anak dimiliki anak tentunaya kita sebagai pendidik harus mempunyai cara atau tekhnik untuk mengembangkan hal tersebut. Adapun dalam penelitian ini memilih salah satu metode yaitu metode proyek untuk mengembangkan kemampuan kognitif anak.

Metode proyek merupakan salah satu cara pemberian pengalaman dengan menghadapkan anak dengan persoalan-persoalan yang dihadapi dalam kehidupan sehari-harinya dan harus dipecahkan secara berkelompok, Dengan metode ini maka anak dilatih untuk mengerjakan pekerjaannya dengan sendiri-sendirinya dan tidak bergantung pada temannya ataupun orang lain karena adanya pekerjaan tersendiri yang harus dikerjakan dalam suatu kelompok tersebut. Menggunakan metode proyek maka anak memperoleh pengalaman belajar secara langsung, baik dalam hal pekerjaan dan tanggung jawab yang dialaminya dalam kehidupan sehari-harinya, sehingga anak dilatih untuk melakukan pekerjaan yang mampu melatih kemampuan kognitifnya, agar anak 
mampu menyelesaikannya melalui metode proyek.

Perkembangan anak pada masa usia dini berjalan lebih cepat dari usia sesudahnya, olehnya karena itu pada masa usia dini anak dibekali pembelajaran yang mampu merangsang kinerja otaknya dan sel-sel sarafnya agar berkembang dengan baik. Sebagaimana yang dikemukan oleh Manispal (2013: 79) bahwa:

Perkembangan anak usia dini berjalan cepat, bahkan lebih cepat dari usia sesudahnya, hal ini berkaitan dengan optimalisasi fungsi sel-sel saraf (neuron) otak manusia terdiri dari dua belahan (hamisfer), kiri dan kanan berisi miliaran neuron.

Perkembangan anak sejak dalam kandungan, merangsang sel-sel saraf tersebut berkembang mengikuti pengalaman-pengalaman yang dilakukan anak, karena semakin banyak pengalaman-pengalaman yang dilakukan anak maka semakin berkembang pula sel-sel neuron yang diterima pada sel-sel sarafnya, karena dengan adanya stimulasi-stimulasi rangsangan yang diberikan pada anak sejak dalam kandungan maka akan membuat sel-sel neuron tersebut bergerak lebih cepat dari yang sebelumnya.

Berdasarkan dari hasil observasi yang dilaksanakan di TK Aisyiyah Maccini Tengah Kota Makassar, anak-anak yang berada dikelas B2 yang berjumlah 16 orang anak, 10 orang anak perempuan 6 orang anak laki-laki. Beberapa anak yang masih mengalami kesulitan dalam melakukan sesuatu yang berhubungan dengan kemampuan kognitifnya. Hal ini terlihat pada saat guru menjelaskan kepada anak tentang bentuk-bentuk geometri, menjumlahkan angka, dan menyusun suatu benda dari yang besar ke yang kecil dan anak belum bisa melakukan hal tersebut dengan sendirinya.

Sejalan dengan ini menandakan bahwa, daya tingkat pemahaman anak masih kurang, dimana ada beberapa anak yang belum bisa merespon dengan baik tentang apa yang dijelaskan oleh gurunya, untuk menghubungkan, menilai dan mempertimbangkan dari suatu kejadian yang telah diberikan, Karena kurang stimulasi yang diberikan pada anak didik. Hal ini dapat dilihat ketika anak diperlihatkan dengan bentuk-bentuk geometri anak belum bisa membedakan bentukbentuk geometri, dan mengurutkan benda sesuai dengan jenisnya.
Tingkat kemampuan kognitif anak dapat dilihat di Kelas B2 yang berjumlah 16 orang anak, ada 13 orang anak yang belum mampu mengetahui tentang bentuk-bentuk geometri, meniru pola dan sebagainya, dan 3 orang anak diantaranya sudah mampu melakukan hal tersebut. Hal ini disebabkan karena kurangnya kegiatan yang mampu melatih kamampuan kognitif anak dan kurangnya minat anak didik dalam melakukan kegiatan yang tidak menarik bagi anak untuk ia kerjakan.

Kemampuan daya pemahaman anak dapat dilihat bahwa lebih banyak anak yang belum mampu dibandingkan anak yang sudah mampu melakukan kegiatan yang mampu mengembangkan kemampuan kognitifnya sebagaimana yang dikemukakan oleh Alfred Binet (Sujiono, 2009: 1.14) yaitu:

Potensi kognitif seseorang tercermin dalam kemampuan menyelesaikan tugas-tugas yang menyangkut pemahaman dan penalaran perwujudan potensi kognitif manusia harus dimengerti sebagai suatu aktivitas atau prilaku kognitif yang pokok, terutama pemahaman penilaian dan pemahaman baik yang menyankut kemampuan berbahasa maupun yang menyangkut kemampuan motorik.

Kemampuan kognitif anak merupakan suatu tingkat kecerdasan yang berhubungan dengan proses berpikir anak melalui kemampuan panca indera, untuk menghubungkan, menilai dan mempertimbangka dari suatu kejadian ataupun peristiwa yang dialaminya, baik secara lansung ataupun tidak langsung sehingga anak dapat menyimpulkan tentang apa yang ia dapatkan dari suatu kejadian yang dialaminya.

Berdasarkan dari uraian yang telah dipaparkan sebelumnya, maka peneliti tertarik untuk melakukan penelitian dengan judul Pengaruh Metode Proyek Terhadap Kemampuan Kognitif Anak di Kelompok B2 TK Aisyiyah Maccini Tengah Kota Makassar dengan menggunakan beberapa kegiatan untuk melatih kemampuan kognitif anak.

Berdasarkan dari latar belakang yang telah dipaparkan sebelumnya, maka rumusan masalah dari penelitian ini yaitu:

1. Bagaimana kemampuan kognitif anak di kelompok B2 TK Aisyiyah Maccini Tengah Kota Makassar sebelum dan sesudah diberikan perlakuan metode proyek? 
2. Apakah ada pengaruh metode proyek terhadap kemampuan kognitif anak di Kelompok B2 TK Aisyiyah Maccini Tengah Kota Makassar?

Berdasarkan dari rumusan masalah yang telah dipaparkan, maka untuk mengetahui tujuan penelitian ini: (1) Mendiskripsikan kemampuan kognitif anak dikelompok B2 TK Aisyiyah Maccini Tengah Kota Makassar sebelum dan sesudah diberikan perlakuan metode proyek. (2) Mendiskripsikan pengaruh metode proyek terhadap kemampuan kognitif anak di Kelompok B2 TK Aisyiyah Maccini Tengah Kota Makassar.

\section{METODE PENELITIAN}

Penelitian ini adalah bersifat kuantitatif dengan menggunakan pendekatan eksperimen sederhana. Sebagaimana yang dikemukakan oleh Sugiono (2013: 109) yang mengemukakan bahwa "pre-experimental design, karena desain ini belum merupakan eksperimen sungguhsungguh karena masih terdapat variabel luar yang ikut berpengaruh terhadap terbentuknya variabel independen". Dalam penelitian ini peneliti menggunakan One-Group PretestPosttest Design.

Variabel ini terdiri dari dua variabel yaitu variabel bebas dan variabel terikat. Dimana pada variabel bebas merupakan variabel yang mempengaruhi diamana pada pengaruh metode proyek merupakan variabel bebas. Sedangkan variabel terikat yaitu variabel yang dipengaruhi dan dimana pada penelitian ini yang menjadi variabel terikat yaitu kemampuan kognitif anak.

Desain penelitian ini merupakan desain penilitian yang menggunakan desain One-Group Prestest-Posttest, sebagaimana yang dikemukakan oleh Sugiono (2010: 110) tentang desain penelitian tersebut yang mengatakan bahwa "pada desain ini terdapat pretest, sebelum diberi perlakuan. Dengan demikian hasil perlakuan dapat diketahui lebih akurat, karena dapat membandingkan dengan keadaan sebelum diberi perlaukan". Sebagaimana desain penelitian tersebut sebagai berikut:

\section{$\mathrm{O}_{1} \times \mathrm{O}_{2}$}

Gambar 3.1 Desain Penelitian

Keterangan: $\mathrm{o}_{1}$ : Nilai pretest kemampuan kognitif anak (sebelum diberi perlakuan)

$\mathrm{x}$ : Perlakuan (treatment) yaitu metode proyek $\mathrm{o}_{2}$ : Nilai posttest kemampuan kognitif anak (setelah diberi perlakuan)

Adapun hipotesis yang di gambarkan dalam penelitian ini yaitu sebagai berikut:

H0: Tidak ada pengaruh metode proyek terhadap kemampuan kognitif anak

H1 : Ada pengaruh metode proyek terhadap kemampuan kognitif anak

Defenisi operasional penelitian dimaksudkan agar tidak terjadi suatu kesalahan dalam tahap proses penafsiran dalam suatu variabel yang telah ditentukan. Berikut ini adalah defenisi operasional variabel:

1. Metode proyek

Metode proyek merupakan metode yang diberikan pada anak melalui pemberian pengalaman belajar secara kelompok, dengan pembagian pekerjaan masing-masing yang telah diberikan kepada anak. Dengan dihadapkan pada persoalan-persoalan sehari-hari yang dipecahkan secara bersama-sama untuk memecahkan masalah tersebut.

\section{Kemampuan kognitif}

Kemampuan kognitif merupakan suatu proses berfikir untuk menghubungkan, menilai, dan mempertimbangkan suatau kejadian atau peristiwa yang dialami anak. proses kognitif berhubungan dengan tingkat kecerdasan yang menandai seseorang dengan berbagai minat terutama ditujukan pada kemampuan ide-ide belajar seseorang.

Menurut Tiro (2008: 3) "Populasi didefenisikan sebagai keseluruhan aspek tertentu dari ciri, fenomena atau konsep (misalnya berat badan, nilai EBTANAS dan sebagainya) yang menjadi pusat perhatian" dan sampel merupakan sejumlah anggota yang dipilih atau diambil dari suatu populasi yang kita ambil untuk dijadikan sampel.

Populasi dalam penelitian ini merupakan jumlah keseluruhan anak didik dikelompok A dan kelompok B di TK Aisiyiyah Maccini Tengah Kota Makassar. yang terdiri dari 5 kelompok, yaitu kelompok A1, B1, B2, B3, dan B4. Teknik pengambilan sampel yang digunakan dalam penelitian ini adalah teknik purposive sampling. Sugiyono (2010: 124) menjelaskan bahwa "Purposive sampling adalah teknik penentuan sampel dengan pertimbangan tertentu." Sampel yang digunakan dalam penelitian ini hanya satu kelompok yaitu 
kelompok B2 yang terdiri dari 16 anak didik berusia 5-6 tahun.

Teknik pengumpulan data merupakan cara atau jalan yang digunakan oleh peneliti untuk mengumpulkan data dalam penelitian, dan untuk mendapatkan data yang akurat dalam penulisan ini. Penelitian menyusun dan menyiapkan beberapa teknik pengumpulan data untuk menjawab pertanyaan penelitian ini, yaitu observasi dan dokumentasi.

Dalam prosedur pengumpulan data ada beberapa cara yang dilakukan untuk mendapatkan data dalam penelitian ini, adapun prosedur yang dilakukan yaitu perencanaan, Pemberian pretest, Pemberian Perlakuan treatment, Pemberian posttest, Analisis Hasil.

Analisis Data yang diperoleh yaitu dengan menceklis kemampuan kognitif anak pada lembar observasi, sesuai dengan kategori yang digunakan dan telah dirubah dalam angka-angka sebagai nilai yang dicapai dengan menggunakan skala pengukuran terlihat pada tabel berikut ini :

Tabel 3.2 Pengukuran Kemampuan Kognitif Menurut Yus (2011: 126)

\begin{tabular}{lcc}
\hline No & Kategori & Nilai \\
\hline 1 & Baik & 3 \\
\hline 2 & Cukup & 2 \\
\hline 3 & Kurang & 1 \\
\hline
\end{tabular}

Setelah memperoleh data-data dengan memberi nilai pada penilaian instrumen yang digunakan, kemudian menentukan banyaknya kelas interval sebagaimana yang dikemukakan oleh Tiro (2008: 98) sebagai berikut:

Untuk menentukan banyaknya kelas interval dengan berbagai pertimbangan antara lain: (1) banyaknya data, (2) nilai terendah dan tertinggi yang ada pada kumpulan data, dan (3) menghindari terlalu sedikit atau terlalu banyaknya kelas interval.

Setelah semua data yang diperoleh sebelum dan sesudah melakukan metode proyek selanjutnya dianalisis menggunakan statistik deskriktif dan statistik nonparametrik.

1. Statistik deskriptif dimaksudkan untuk menggambarkan kemampuan kognitif anak sebelum dan sesudah melakukan perlakuan dengan menggunakan metode proyek dengan mengumpulkan data dari jumlah nilai yang dicapai anak berdasarkan hasil observasi yang telah dilakukan, selanjutnya guna memperoleh gambaran umum mengenai rata-rata tingkat kemampuan kognitif anak sebagaimana yang telah dirumuskan oleh Sudijono (2015: 81) dengan perhitungan rata-rata sebagai berikut:

$$
\begin{array}{ll}
P=\frac{\sum x}{N} \\
\text { Dimana: } & \\
\mathrm{P}= & \text { Rata-rata } \\
\mathrm{X}= & \text { Nilai/Harga } \mathrm{x} \\
\mathrm{N}= & \text { Jumlah Data }
\end{array}
$$

2. Statistik nonparametrik digunakan dengan alasan bahwa dapat menggarap data yang merupakan peringkat. Untuk analisis uji beda digunakan analisis uji beda Wilcoxon

\section{HASIL DAN PEMBAHASAN}

Gambaran umum lokasi penelitian dalam bab ini, akan dideskripsikan mengenai hasil pengelolahan dan pembahasan penelitian yang telah dilakukan, dan akan diperlihatkan kemampuan kognitif anak yang telah dilakukan melalui metode proyek. Data tentang hasil penelitian diperoleh melalui lembar observasi dan dianalisis secara akurat.

\subsection{Gambaran penerapan metode proyek}

Metode proyek merupakan suatu bentuk perlakuan yang diberikan kepada anak untuk meningkatkan kemampuan kognitif anak. Penelitian ini dilakukan di TK Aisyiyah Maccini Tengah Kota Makassar, yang dimulai sejak tanggal 18 Juli-18 Agustus 2016. Pemberian perlakuan metode proyek dilakukan sebanyak 6 kali, pertemuan dilakukan selama 3 minggu dalam pelaksanaan penelitian. Pada pertemuan pertama peneliti melakukan pretest dan pada pertemuan kedua dan terakhir minggu ketiga peneliti melakukan Posttest.

Penerapan metode proyek disesuaikan dengan tema pembelajaran di TK Aisyiyah Maccini Tengah Kota Makassar, yaitu tema diriku, dan diri sendiri dengan sub tema tubuhku dan kesukaanku. Dalam kegiatan yang diberikan dengan penerapan metode proyek ada tiga kegiatan yang digunakan yaitu: Menggelompokkan bentuk-bentuk geometri, mengurutkan angka 1-20, dan menyusun pola balok. Setiap kegiatan dilaksanakan secara berkelompok agar anak mampu bekerja sama dengan teman-temannya sesuai dengan tugas masing-masing.
3.2. Kemampuan kognitif anak sebelum perlakuan metode proyek 
Berdasarkan dari data hasil observasi awal yang dilakukan, sebelum dan sesudah perlakuan dengan menggunakan metode proyek yang dilaksanakan di TK Aisyiyah Maccini Tengah Kota Makassar sesuai dengan kemampuan indikator yang digunakan dapat dilihat pada tabel sebagai berikut:

Berdasarkan uraian dari tabel yang telah dipaparkan, maka dapat disimpulkan bahwa dari 16 anak hanya sebagian kecil yang mempunyai kemampuan kognitif yang berhasil dan belum berhasil setelah dilakukan test. Adapun data yang diperoleh sebelum menggunakan metode proyek pada dengan kemampuan kognitif anak berdasarkan kategori kurang, cukup, dan baik. Hal ini dapat dilihat pada kategori kemampuan kognitif anak pada tabel sebagai berikut:

Indikator Kemampuan Kognitif Sebelum Perlakuan Metode Proyek

\begin{tabular}{|c|c|c|c|c|}
\hline $\begin{array}{l}\mathrm{N} \\
\mathrm{O}\end{array}$ & $\begin{array}{c}\text { Interva } \\
1\end{array}$ & $\begin{array}{c}\text { Katego } \\
\text { ri }\end{array}$ & $\begin{array}{c}\text { Frekue } \\
\text { nsi }\end{array}$ & Persentase \\
\hline 1 & $17-21$ & Baik & - & $0 \%$ \\
\hline 2 & $12-16$ & Cukup & 2 & $12,5 \%$ \\
\hline 3 & $7-11$ & Kurang & 14 & $87,5 \%$ \\
\hline \multicolumn{3}{|c|}{ Jumlah } & 16 & $100 \%$ \\
\hline
\end{tabular}

Berdasarkan pada tabel diatas dapat diketahui bahwa 0 anak pada interval 17-21 yang dikategorikan baik, kemudian ada 2 orang anak yang berada pada interval 12-16 yang dikategorikan cukup dan 14 orang anak pada interval 7-11 dikategorikan kurang. Dengan demikian dapat diketahui bahwa kemampuan kognitif anak sebelum diberi perlakuan berupa metode proyek menunjukkan bahwa dari 16 jumlah anak, 0\% berada pada kategori baik, $12,5 \%$ berada pada kategori cukup dan $87,5 \%$ berada pada kategori kurang.

\subsection{Kemampuan kognitif anak sesudah perlakuan metode proyek}

Berdasarkan dari data hasil observasi akhir yang telah dilakukan, maka dapat dilampirkan dengan tabel sesudah perlakuan dengan menggunakan metode proyek yang dilaksanakan di TK Aisyiyah Maccini Tengah Kota Makassar. Kemudian sesuai dengan tingkat kemampuan indikator yang digunakan, dan dapat dilihat pada tabel sebagai berikut:

Berdasarkan pada uraian tabel yang telah dipaparkan, maka dapat disimpulkan bahwa dari 16 anak sebagian besar telah mengalami perkembangan kemampuan kognitif dengan kategori baik dan cukup. Adapun data yang diperoleh setelah perlakuan metode proyek pada frekuensi kemampuan kognitif anak berdasarkan kategori kurang, cukup dan baik. Hal ini dapat dilihat pada tabel sebagai berikut:

\begin{tabular}{|c|c|c|c|c|}
\hline $\mathrm{N}$ & $\begin{array}{c}\text { Interva } \\
1\end{array}$ & $\begin{array}{c}\text { Katego } \\
\text { ri }\end{array}$ & $\begin{array}{c}\text { Frekue } \\
\text { nsi }\end{array}$ & Persentase \\
\hline 1 & $17-21$ & Baik & 2 & $12,5 \%$ \\
\hline 2 & $12-16$ & Cukup & 2 & $25 \%$ \\
\hline 3 & $7-11$ & Kurang & 10 & $62,5 \%$ \\
\hline \multicolumn{3}{|c|}{ Jumlah } & 16 & $100 \%$ \\
\hline
\end{tabular}

Berdasarkan pada tabel diatas dapat diketahui bahwa ada 2 anak yang berada pada interval 17-21 yang dikategorikan baik, kemudian ada 4 anak yang berada pada kategori interval 12-16 yang dikategorikan cukup, dan 10 anak pada interval 7-11 yang dikategorikan kurang. Dengan demikian dapat diketahui bahwa kemampuan kognitif anak sesudah diberi perlakuan berupa metode proyek menunjukkan bahwa dari 16 jumlah anak, $12,5 \%$ berada pada kategori baik, 25\% berada pada kategori cukup, dan $62,5 \%$ berada pada kategori kurang.

\subsection{Pengaruh metode proyek terhadap kemampuan kognitif anak \\ Hasil penelitian yang diperoleh} berdasarkan dari data hasil observasi awal dan akhir yang telah dilakukan, maka dapat diketahui bahwa pengaruh metode proyek terhadap kemampuan kognitif anak setelah dilakukannya uji hipotesis dengan analisis uji wilcoxon. Adapun langkah-langkah yang dilakukan untuk mengetahui pengaruh metode proyek terhadap kemampuan kognitif anak sebagai berikut:

a. Data sebelum (O1) dan sesudah (O2) diperlakukan dan ditetapkan dengan beda selisih skor

b. Membuat rangking dari keseluruhan jumlah anak, dengan cara mengurutkan nilai dari yang tertinggi sampai ke yang rendah, kemudian dari atas diberi angka yang menunjukkan rangking mulai dari angka 1,2,3 dan seterusnya. Kemudian nilai yang sama harus diberikan rangking yang sama pula, dengan membagi bilangan nilai rangking secara adil kepada semua pemilik nilai yang sama. Dengan tanda setiap rangking dengan tanda (+atau-)

c. Untuk menetapkan nilai $\mathrm{T}$ maka tanda yang terkecil dijumlahkan dari kedua kelompok rangking yang memiliki tanda yang sama dan nilai $\mathrm{N}$ didapatkan dari jumlah sampel yang diteliti. 
d. Kemudian dilakukan perbandingan antara nilai $\mathrm{T}$ yang diperoleh dengan nilai $\mathrm{T}$ pada uji bertanda Wilcoxon (Siegel, 992: 103).

Kemampuan kognitif anak yang ditemukan sebelum dan sesudah melakukan kegiatan metode proyek, menunjukkan bahwa jumlah rangking yang bertanda poritif $(+)=136$ dan jumlah rangking yang bertanda negative $(-)=0$, maka $\mathrm{T}$ merupakan jumlah dari rangking yang lebih kecil. Dalam pengambilan keputusan jika $\mathrm{T}$ hitung $<\mathrm{T}$ tabel $=\mathrm{H} 0$ diterima $\mathrm{H} 1$ ditolak artinya tidak ada pengaruh metode proyek terhadap kemampuan kognitif anak dikelompok B2 TK Aisyiyah Maccini tengah Kota Makassar. Jika $\mathrm{T}$ hitung $>$ tabel $=\mathrm{H} 0$ ditolak $\mathrm{H} 1$ diterima artinya ada penagaruh metode proyek terhadap kemampuan kognitif anak dikelompok B2 TK Aisyiyah Maccini Tengah Kota Makassar.

Jika $\mathrm{Z}$ hitung $<\mathrm{Z}$ tabel $=\mathrm{H} 0$ diterima $\mathrm{H} 1$ ditolak artinya tidak ada pengaruh metode proyek terhadap kemampuan kognitif anak dikelompok B2 TK Aisyiyah Maccini Tengah Kota Makassar. Jika Z hitung $>\mathrm{Z}$ tabel $=\mathrm{H} 0$ ditolak H1 diterima artinya ada pengaruh metode proyek terhadap kemampuan kognitif anak di TK Aisyiyah Maccini Tengah Kota Makassar.

Adapun nilai $\mathrm{T}$ hitung yang diperoleh yaitu 136 dan $\mathrm{T}$ tabel 30 maka hasil yang diperoleh dari $\mathrm{T}$ hitung (136) > T tabel (30) maka H0 ditolak dan $\mathrm{H} 1$ diterima. Yang artinya ada pengaruh metode proyek terhadap kemampuan kognitif anak dikelompok B2 TK Aisyiyah Maccini Tengah Kota Makassar. Sedangkan nilai $\mathrm{Z}$ hitung yang diperoleh yaitu 3,51 dan $\mathrm{Z}$ tabel $\alpha 0,05=1.645$ Maka diperoleh hasil $Z$ hitung $(3,51)>Z$ tabel $(1,645)$ maka H0 ditolak dan $\mathrm{H} 1$ diterima artinya ada pengaruh metode proyek terhadap kemampuan kognitif anak dikelompok B2 TK aisyiyah Maccini Tengah Kota Makassar. Hal tersebut menunjukkan bahwa kemampuan kognitif anak menerima perlakuan dengan menggunakan metode proyek dengan baik dibandingkan sebelum dilakukan perlakuan metode proyek, yang artinya terjadi peningkatan perolehan nilai setelah diberikan perlakuan. Berdasarkan uraian yang telah dipaparkan diatas maka dapat disimpulkan bahwa, perlakuan metode proyek berpengaruh terhadap kemampuan kognitif anak.

\subsection{Pembahasan}

Hasil penelitian berdasarkan analisis deskriftif pada populasi yang digunakan di TK
Aisyiyah Maccini Tengah Kota Makassar dengan jumlah 16 orang anak, yang berada dikelompok B2 dengan usia 5-6 tahun, menunjukkan bahwa sebelum perlakuan dengan kegiatan metode proyek anak belum mampu mengelompokkan bentuk geometri, mengurutkan angka, dan meyusun pola. Hal ini dapat dilihat bahwa kemampuan kognitif untuk menghubungkan, menilai, dan mempertimbangkan masih rendah.

Sebagaimana teori yang telah paparkan pada tinjauan pustaka oleh Susanto (2011: 47) yang mengemukakan tentang perkembangan kognitif, sebagai berikut:

Kognitif adalah suatu proses berfikir, yaitu individu untuk menghubungkan, menilai, dan mempertimbangkan suatu kejadian atau peristiwa. Proses kognitif berhubungan dengan tingkat kecerdasan (intelegensi) yang menandai seseorang dengan berbagai minat terutama sekali ditujukan kepada ide-ide dan belajar.

Hasil penelitian berdasarkan analisis deskriftif setelah diberikan perlakuan untuk mengetahui tingkat kemampuan kognitif anak dengan menggunakan metode proyek, dapat dilihat bahwa kemampuan untuk menghubungkan, menilai, dan mempertimbangkan dengan melakukan kegiatan mengelompokkan bentuk-bentuk geometri, mengurutkan angka 1-20, dan menyusun pola menjadi bentuk rumah sudah berkembang dengan baik.

Berdasarkan pemaparan yang telah dijelaskan, guna mendukung hipotesis yang telah dirumuskan sebelumnya, maka dengan diterimanya hipotesis (H1) yang menunjukkan bahwa adanya pengaruh yang terjadi dari perlakuan dengan menggunakan metode proyek di Kelompok B2 TK Aisyiyah Maccini Tengah Kota Makassar, artinya kemampuan kognitif anak berkembang dengan baik setelah dilakukannya perlakuan dengan menggunakan metode proyek.

\section{SIMPULAN DAN SARAN}

Berdasarkan data yang telah diperoleh pada hasil observasi awal dan sesudah hasil observasi akhir setelah melakukan metode proyek dapat disimpulkan sebagai berikut:

1. Kemampuan kognitif anak sebelum diberikan perlakuan dengan menggunakan metode proyek dapat dilihat bahwa anak belum mampu untuk menghubungkan, 
menilai, dan mempertimbangkan sesuatu yang ia kerjakan. Seperti halnya anak belum mampu mengelompokkan bentuk-bentuk geometri, mengurutkan angka, dan menyusun pola. Kemampuan kognitif anak sesudah diberikan perlakuan dengan menggunakan metode proyek dapat dilihat bahwa anak sudah mampu untuk menghubungkan, menilai, dan mempertimbangkan sesuatu yang ia kerjakan. Seperti halnya anak sudah mampu mengelompokkan bentuk-bentuk geometri, mengurutkan angka, dan menyusun pola.

2. Pemberian metode pembelajaran dengan menggunakan metode proyek dapat berpengaruh terhadap tingkat kemampuan kognitif anak. Hal ini sesuai dengan hasil penelitian yang ditemukan bahwa anak mampu untuk menghubungkan, menilai dan mempertimbangkan sesuatu yang ia kerjakan. Dengan menggunakan beberapa kegiatan yaitu: Mengelompokkan, mengurutkan, dan menyusun pola. Hal ini menunjukkan bahwa metode proyek memiliki pengaruh positif untuk meningkatkan kemampuan kognitif anak.

Berdasarkan temuan yang berkaitan dengan hasil penelitian tentang pengaruh metode proyek terhadap kemampuan kognitif anak, maka dapat dikemukakan beberapa saran sebagai berikut :

1. Bagi guru taman kanak-kanak sebagai pelaksana proses pembelajaran di kelas, hendaknya dapat semaksimal mungkin meningkatkan keterampilan dan kemampuan yang dimiliki anak, dengan menciptakan berbagai situasi pembelajaran dengan menggunakan beberapa metode salah satunya dengan menggunakan metode proyek yang mampu meningkatkan kemampuan kognitif anak dengan tugas masing-masing yang telah diberikan dengan proses pembelajaran kelompok.

2. Bagi orang tua hendaknya melatih kemampuan kognitif anak dengan melatih untuk mengerjakan sesuatu dengan kemampuan untuk menghubungkan, meniali, dan mempertimbangkan sesuatu yang ia kerjakan.

3. Bagi calon peneliti berikutnya, sebaiknya memberikan metode-metode pengajaran yang menarik bagi anak untuk ia kerjakan agar dapat memperoleh hasil yang lebih baik lagi.

\section{DAFTAR PUSTAKA}

Ahmad, Kasina., dan Hikmah. 2005. Perlindungan dan Pengasuhan Anak Usia Dini. Jakarta. Departemen Pendidikan Nasional Direktorat Jenderal Pendidikan Tinggi Direktorat Pembinaan Pendidikan Tenaga Kependidikan dan Ketanagaan Perguruan Tinggi

Desmita. 2013. Psikologi Perkembangan. Bandung. PT Remaja Roskadarya Offset Bandung

Departemen Pendidikan Nasional Direktorat Jenderal Pendidikan Dasar dan Menegah Direktorat Pembinaan Taman Kanak-kanak dan Sekolah Dasar, 2007. Pedoman Pembelajaran Bidang Pengembangan Kognitif di Taman Kanak-kanak. Jakarta. Departemen Pendidikan Nasional

Haenilah, Een Y. 2015. Kurikulum dan Pembelajaran Paud. Yogyakarta. Media Akademi

Moeslichatoen. 2004. Metode Pengajaran Di Taman Kanak-kanak. Jakarta. PT Rineka Cipta

Manispal. 2013. Siap Menjadi Guru dan Pengelola PAUD Profesional. Jakarta. PT Elex Media Komputindo

Peraturan Menteri Pendidikan dan Kebudayaan Republik Indonesia Nomor 146 Tahun 2014 tentang Kurikulum 2013 pendidikan anak usia dini. Jakarta. Kementrian Pendidikan dan Kebudayaan

Rachmawati, Yeni., Kurniati, Euis. 2012. Strategi Pengembangan Kreativitas Anak Usia Dini. Jakarta. Kencana

Sinring, Abdullah dkk. 2012. Pedoman Penulisan Skripsi Program S-1 Fakultas Ilmu Pendidikan UNM. Makassar. Fakultas Ilmu Pendidikan Universitas Negeri Makassar

Siegel, Sidney. 1992. Statistik Nonparametrik. Jakarta: PT Gramedia Pustaka Utama

Sujiono, Yuliani Nurani. 2009. Metode Pengembangan Kognitif. Jakarta. Universitas Terbuka 2011. Konsep Dasar

Pendidikan Anak Usia Dini. Jakarta. PT indeks 
Susanto, Ahmad. 2011. Perkembangan Anak Usia Dini. Jakarta. Kencana Prenadamedia Group

Sugiyono. 2010. Metode Penelitian Pendidikan (Pendekatan Kuantitatif, Kualitatif dan $R \& D)$. Bandung. Alfabeta

Sudijono, Ansar. 2015. Pengantar Statistik Pendidikan. Jakarta. Rajawali Fers

Triharso, Agung. 2013. Permainan Kreatif dan Edukatif untuk Anak Usia Dini. Yogyakarta. CV Andi Ofsset

Tiro, Muhammad Arif. 2008. Dasar-Dasar Statistika (edisi III). Makassar. Andira Publisher

Wahyudin, Uyu., dan Mubiar, Agustin. 2102. Penilaian Perkembangan Anak Usia Dini. Bandung. PT Refika Aditama

Yus, Anita. 2011. Penilaian Perkembangan Belajar Anak Taman Kanak-kanak. Jakarta: Kencan. 